\title{
ALTERASI FITUR FONOLOGIS BAHASA BALI PASIEN AFASIA BROCA
}

\author{
ALTERATION OF PHONOLOGICAL FEATURES IN BALINESE SPEECH OF BROCA'S \\ APHASICS
}

\author{
I Ketut Wardana
}

\author{
Fakultas Keguruan dan Ilmu Pendidikan Universitas Mahasaraswati Denpasar \\ Jalan Kamboja, 11A Denpasar, Bali, Indonesia \\ wardanak3tut@yahoo.co.id
}

\begin{abstract}
(Naskah diterima tanggal 7 Mei 2020, direvisi terakhir tanggal 2 Juni 2021, dan disetujui tanggal 26 November 2021)
\end{abstract}

DOI: https:/ / doi.org/10.26499/wdprw.v49i2.673

\begin{abstract}
The determination of phonological alteration patterns of speech disorder of Broca aphasia is the scope of neurolinguistic study that needs more attention. Thus, this study investigates the alteration of the phonological feature in Broca's aphasics. This phenomenology-based research involves the observation of two patients with non-hemorrhagic stroke with impaired language modalities such as spontaneous speech, naming, reading, writing, but intact comprehension. Data was collected from the observation method with listening, involvement, conversation, and noting. The data were recorded with Sonny voice recorder. The instruments for language modality measurements were 65 picture lists, 65-word lists, 1 sheet of conversation script, and 1 reading text. The data analysis provided the implementation of generative phonology. The results showed that the substitution of marked features by less marked features was due to the errors of the articulation planning program. The more complex the articulation of the phonemes, the more often the segments are altered. This study also found the violation of the sonority scale and reconstruction of the syllabic structure. The alteration of segments with the identic place of articulation with features with a different manner of articulation occurs due to phonological neighboring density. So, this study has contributed to clinical recommendations for phonological disorders for neurologists and speech therapists.
\end{abstract}

Keywords: aphasia; alteration; phonological feature; neurolinguistics

\begin{abstract}
Abstrak
Penetapan pola alterasi fonologis pada gangguan bunyi afasia Broca merupakan ruang lingkup kajian neurolinguistik yang belum begitu banyak menjadi perhatian. Penelitian ini mengkaji jenis dan pola alterasi fitur fonologis tuturan bahasa Bali pasien afasia Broca. Penelitian deskriptif berbasis fenomenologi ini melibatkan dua pasien stroke nonhemoragik $(\mathrm{SNH})$ dengan pelemahan modalitas bahasa, seperti terbatabata, penamaan, membaca, menulis, namun keupayaan pemahaman masih baik. Data dikumpulkan melalui metode pengamatan dengan teknik simak, libat, cakap, dan catat. Semua data direkam dengan Sonny voice recorder. Instrumen untuk mengukur modalitas bahasa menggunakan 65 daftar gambar, 65 daftar, kata, 1 skrip percakapan, dan 1 teks bacaan. Semua alterasi bunyi ujaran dianalisis melalui fonologi generatif. Hasil penelitian menunjukkan adanya alterasi fitur-fitur bermarkah di semua distribusi oleh fitur yang kurang bermarkah karena konsep artikulasi yang keliru. Semakin tinggi kompleksitas artikulasi bunyi target, semakin sering bunyi tersebut mengalami alterasi. Fitur bunyi dengan kompleksitas yang tinggi [+hambat] cenderung diganti dengan fitur bunyi yang kompleksitas artikulasinya setingkat lebih rendah [+frikatif]. Fonem dengan fitur fonologis bermarkah mengalami proses penyederhanaan melalui alterasi bunyi dalam bentuk substitusi, pelesapan, penyisipan, penambahan,
\end{abstract}


dan mutasi. Alterasi terjadi berdasarkan kesamaan fitur tempat artikulasi, namun berbeda pada cara artikulasinya. Hasil penelitian ini dapat menjadi petunjuk ilmiah baik bagi disiplin ilmu klinisi bahasa maupun terapis gangguan berbahasa.

Kata-kata kunci: afasia;, alterasi; fitur fonologis; neurolinguistik

\section{Pendahuluan}

Afasia Broca merupakan pelemahan bahasa yang dikuasai oleh penutur akibat kerusakan di area konvolusi ketiga belahan sisi kiri otak akibat gangguan peredaran darah otak atau stroke (Sastra, 2011: 6). Kerusakan tersebut mengakibatkan pasien kehilangan kemampuan untuk berbicara spontan, mengulang, menyebutkan, membaca dan menulis. Ujaran pasien afasia Broca pada umumnya tidak fasih dan terdiri atas satu atau dua kata, kebanyakan kata dasar (Bastiaanse dkk., 1994: 248). Pasien afasia menyederhanakan bunyi yang tingkat artikulasinya kompleks melalui alterasi fonologis dalam tuturan mereka. Alterasi fonologis bisa dalam bentuk pergantian, pelesapan, penyisipan, penambahan dan metatesis segmen bunyi Selain penyederhanaan bunyi, Adam, (2014: 154) menyatakan bahwa ujaran afasia Broca mengalami distorsi atau ketidakakuratan kualitas penyuaraan bunyi, tekanan, dan pemanjangan bunyi. Cera \& Ortiz (2010: 59) menganggap distorsi melalui pemanjangan dan devoicing bukanlah jenis pergantian karena satu fonem diganti dengan fonem yang lain.

Alterasi fonologis terjadi bukan akibat pelemahan pada fungsi program pemetaan fonem namun karena ada defisit pada implementasi perencanaan fonetis (Gandour, 1998: 212). Pasien afasia menyederhanakan fonem target dengan fonem yang lain, baik yang memiliki fitur yang sama maupun berbeda. Bahkan, terdapat pergantian kaidah struktur internal suku kata dengan mengulang suku kata pertama, memutasi suku kata kedua atau mengulang suku kata terakhir. Misalnya, kata bahasa Bali batu /batu/ 'batu' direalisasikan [toh..batuh]. Artinya, terdapat perubahan konstruksi suku kata karena penambahan fonem konsonan $(\mathrm{K})$ atau vokal (V), yaitu dari /KV.KV/ menjadi [KVK.KV.KVK] Pasien juga menambah suku kata terakhir. Kata kasea /kasə/ 'kain kafan' direalisasikan [sasə..sə], yaitu dari /KV.KV/ menjadi [KV.KV.KV].

Dalam rangkaian segmen bunyi, sonoritas mengatur jalannya segmen dari margin ke inti yang dikenal dengan istilah sonority sequencing principle (SSP). Metode ini mengatur fitur-fitur untuk awal dan akhir suku kata dan kombinasi dalam batasan suku. Misalnya, konsonana deret Bahasa Bali mengizinkan / pr / di awal suku kata, seperti kata pripit /pripit/'pelit'. Fitur pembeda ti-dak hanya digunakan untuk mengindikasikan artikulasi, tetapi juga digunakan untuk mengindikasikan kelompok fitur yang menunjukkan perilaku sama dalam proses fonologis (Odden, 2005: 298).

Dari sudut pandang neurolinguistik, Gandour (1998: 207) menjelaskan bahwa kajian fonologi pada ranah fonetik dan fonemik dalam afasia berkaitan dengan representasi neural dari ujaran dan bahasa. Dikotomi tradisional antara gejala kerusakan anterior dan posterior telah diselidiki dalam tahun-tahun terakhir ini. Buckingham \& Christman (2008: 127) menyatakan bahwa kesulitan perencanaan gerakan artikulator untuk ujaran dianggap masalah nonlinguistik (motorik, fonetik) namun merupakan gejala utama afasia Broca setelah stroke Banyak penelitian yang membahas gangguan fono-logis pasien afasia, namun belum banyak yang menyelidiki tentang fitur-fitur pembeda yang mempengaruhi perubahan struktur internal 
suku kata afasia Broca. Pergantian suatu fonem dengan fonem yang lain atau metatesis suatu fonem dari node suku kata tertentu ke arah node yang lain, memerlukan penjelasan melalui ciri pembeda maupun kaidah yang diperbolehkan dan tidak diperbolehkan secara alamiah.

Pemaksaan pergantian fitur atau penyimpangan kaidah suku kata misalnya dalam jenjang sonoritas dapat menghasilkan alterasi fonologis yang parah dan tidak dikenal dalam bahasa tersebut. Penelitian ini mencoba menyelidiki bagaimana pasien afasia Broca merubah bunyi target dengan menyederhanakan fisiologi artikulasi yang kompleks dari perspektif neurolinguistik

Dengan mengetahui bentuk alterasi fonologis, bisa diketahui segmen apa saja yang mengalami perubahan, posisi dan dalam lingkungan segmen apa saja yang dominan mengalami perubahan dalam prinsip rangkaian suku kata. Tujuan penelitian ini yaitu untuk memetakan pola alterasi fonologis tuturan bahasa Bali yang dihasilkan pasien afasia Broca dan menjelaskan peranan fiturfitur bunyi dalam rekonstruksi suku kata melalui teori fonologi generatif (Schane, 1973: 60) dan teori sonoritas dalam afasia (Bastiaanse dkk., 1994: 251). Temuan pemetaan pola alterasi fonologis pada gangguan bunyi pasien afasia Broca ini diharapkan dapat memberikan bukti empiris dan penguatan teoritis kajian neurolinguistik.

Hasil-hasil penelitian sebelumnya menunjukkan bahwa jenis alterasi yang pa-ling sering ditemukan ialah pergantian (Novick dkk., 2010; Cera \& Ortiz (2010: 60). Pergantian bunyi dalam afasia mengindikasikan ketidakmampuan pasien merea-lisasikan bunyi target (Ingram, 2007: 75). Alterasi fonologis tersebut ada pada tataran fonemis dan tataran fonetis (Gandour, 1998: 209). Alterasi terjadi antara fonem-fonem yang berhubungan dekat. Selanjutnya, antara alterasi fonem yang berbeda tersebut melibatkan lebih dari satu ciri pembeda. Pengaruh aspek bahasa penutur juga dapat mempengaruhi pergantian bunyi, misalnya kompleksitas fonem yang rendah diganti dengan fitur fonem dengan kompleksitas yang tinggi melalui penyederhanaan (Galluzzi dkk, 2015: 66). Sebaliknya fitur dengan kompleksitas yang tinggi diganti oleh penutur afasia Broca dengan fitur yang memiliki fitur [+ rendah] (Cera \& Ortiz, 2010: 61).

Bukti yang lain ialah terjadi lebih banyak kebingungan konsonan dari yang diprediksi secara teoritis. Wardana dkk., (2018: 241) menyebutkan bahwa alterasi pergantian satu segmen bunyi dalam suku kata yang dihasilkan oleh penutur dengan afasia Broca memengaruhi perubahan segmen bunyi yang lain pada suku kata berikutnya. Artinya pergantian bunyi melibatkan perubahan konsepkonsep yang melekat pada segmen tersebut. Jika sebuah fitur berubah maka fitur lain juga berubah (Wardana dkk., 2019: 154). Perubahan tersebut mengikuti kaidah hirarki sonoritas dengan fitur-fitur yang tersusun ketat dalam prinsip rangkaian suku kata.

Segmen bunyi dapat disusun berdasarkan hirarki sonoritas atau skala dari yang paling sonoran sampai yang paling tidak sonoran. Semua skala tersebut yang telah diatur sejalan dengan susunan yang menempatkan obstruents (hambat, frikatif, dan afrikat) pada ujung yang paling tidak sonoran, diikuti oleh nasal, liquids, glides ujung yang paling sonoran, yaitu vokal. Bunyi sonoran dicirikan oleh getaran spontan pita suara. (Solomon \& Munson, 2004: 590) menjelaskan bahwa sonoran sebagai konfigurasi rongga mulut dan rahang yang cukup terbuka dengan tekanan udara di dalam dan di luar mulut relatif sama. Alqahtani (2019: 460) menjelaskan sonoran sebagai konsonan yang dilafalkan baik melalui rongga oral maupun ruang hidung relatif bebas dari halangan. Menurut Bastiaanse dkk., (1994: 249), fitur [+sonorant] merupakan ciri utama berdasarkan latar be- 
lakang fonologis bukan berlatar belakang artikulatori karena ciri ini memainkan pera-nan penting dalam proses alamiah. Segmen hirarki sonoritas dimulai dari yang paling tidak sonoran menuju ke yang paling sonoran.

Berbeda dengan fonologi struktural yang menekankan bahwa fonem merupakan satuan bunyi terkecil yang dapat membedakan arti leksikon, fonologi generatif menekankan ciri-ciri pembeda (distinctive features) adalah unit terkecil yang membedakan arti (Schane, 1973: 73). Ciri pembeda itu di-sertai dengan ciri biner, yakni tanda plus dan minus untuk memperlihatkan atribut itu hadir atau tidak. Sehingga, dapat diketahui karakter ruas bunyi yang dihasilkan oleh pasien afasia Broca untuk rehabilitasi bunyi berdasarkan kaidah fonologis (Madden dkk., 2017: 65). Odden (2005: 82) menjelaskan bahwa fonologi generatif terdiri atas tiga pe-ringkat, yakni (1) tingkat representasi lek-sikal, (2) peringkat representasi fonologi, dan (3) peringkat representasi fonetis. Schane (1973: 67) menyatakan bahwa ada tiga komponen yang digunakan sebagai dasar analisis dalam teori fonologi generatif, yaitu: (1) underlying representation (UR) atau representasi dasar dengan notasi //, (2) phonological rules atau kaidah fonologis, dan (3) phonetic representation (PR) atau representasi fonetis yang digambarkan melalui notasi [ ].

Dengan demikian, penelitian ini mengasumsikan bahwa pasien afasia menyederhanakan bunyi yang kompleks melalui pergantian pelesapan, penyisipan, penambahan, metatesis, voicing dan devoicing. Pergantian terjadi mengikuti pola skala sonoritas dan dipengaruhi oleh lingkungan bunyi yang berkerabat. Penelitian ini juga menggarisbawahi adanya pelanggaran aturan sehingga menghasilkan kata yang ti-dak bermakna.

\section{Metode}

Penelitian ini menggunakan pendekatan kualitatif dengan data kuantitatif untuk menje- laskan fenomena alterasi bunyi dan struktur suku kata ujaran pasien afasia Broca. Data penelitian ini diambil dari dua pasien afasia Broca yang dirawat di rumah sakit umum daerah (RSUD) Mangusada di Kabupaten Badung-Bali. KW adalah seorang pria berumur 72 tahun berasal dari Buleleng dan seorang pensiunan guru PNS. Pasien pada saat pertama kali kena stroke nonhemoragik (SNH) mengalami mutisme, keinginan besar untuk berkomunikasi, ujaran terbata-bata namun mengerti apa yang dimaksud (Ingram, 2007: 51). Kerusakan sistem saraf otak berada di zona ekspresi bahasa, dan pelemahan badan sebelah kanan. NS, seorang pria berumur 53 tahun, berprofesi sebagai tukang ukir tinggal di Desa Taman Petang. Pasien kena SNH di area anterior dari hemisfer kiri dengan gejala awal mutisme, terbatabata, dan kesulitan mengawali kata.

Metode pengumpulan data yang diterapkan untuk menyerap informasi yaitu metode observasi, perekaman, dan wawancara. Setiap sesi, pengumpulan data dilaksanakan selama 10 menit dan 4 kali per minggu selama 2 bulan atau selama 16 jam untuk mengetahui karakteristik bunyi dalam satuan kata, frasa, klausa, kalimat, dan wicara. Untuk mengetahui fenomena struktur internal suku kata, sonoritas serta pengaruh fitur terhadap gangguan, pasien diberikan penugasan fonologis, berupa percakapan spontan, menyebutkan kata, menamai gambar dan membaca teks singkat (Herbert, 2004: 26). Bunyi ujaran mereka direkam dengan menggunakan perekam voice recording Sonny Mp3 dan pengamatan melalui pencatatan. Masing-masing pasien menyebutkan masingmasing 65 kata dari semua penugasan.

Segmen-segmen bunyi dalam kata merupakan representasi dari bunyi konsonan, konsonan deret dan vokal di berbagai posisi. Alterasi bunyi dihitung dan diklasifikasikan ke dalam berbagai proses fonologis. Pergerakan pergantian bunyi dalam skala hirarki 
sonoritas dimulai dari kiri ke kanan (5-4-3-21), yaitu kelompok fitur $\{+$ obstruen] $/ \mathrm{p} /$, /b/, /t/, /d/, /k/, /g/,/f/, /v/, /s/, /z/, $/ \mathrm{c} /, / \mathrm{j} / \mathrm{,} \mathrm{h} /(5) \rightarrow[+$ nasal $] / \mathrm{m} /, / \mathrm{n} /, / \mathrm{n} /$, $/ \mathrm{y} /(4) \rightarrow$ [+likuid] $/ 1 /, / \mathrm{r} / \quad$ (3) $\rightarrow$ [+glide/semivokal] /w/, /y/(2) $\rightarrow$ [+Vokal] /i/, /I/, /e/, /o/, /a/, /u/, /o/, /o/, /a/ (1). Alterasi fitur baik secara bertahap maupun meloncati level sebelahnya menuju yang paling sonoran (level 1), seperti terlihat dalam contoh Tabel 1.

Tabel 1

Substitusi Fonem pada Tuturan Afasia Broca

\begin{tabular}{|c|c|c|c|c|}
\hline Kata yang dituju & & Realisasi & Segmen yang dituju & Realisasi segmen \\
\hline ipah /ipah/ & 'ipar' & [aleh] & /p/ (level 5) & [1] (level 3) \\
\hline warung / waron/ & 'warung' & [la luwor] & /r/ (level3) & [1] (level 3) \\
\hline kapak /kapak/ & 'kapak' & [lapak] & /k/ (level 5) & [1] (level 3) \\
\hline sumping / sumpin/ & 'jajan' & [numpin] & /s/ (level 5) & [n] (level 4) \\
\hline lampu /lampu/ & 'lampu' & [lalpu] & /m/ (level 4) & [1] (level 3) \\
\hline nyambu /nambu/ & 'jambu' & [sawob] & /m/ (level 4) & [w] (level 2) \\
\hline guli /guli/ & 'kelereng' & [loli] & /g/ (level 5) & [1] (level 3) \\
\hline
\end{tabular}

Berdasarkan bunyi sebagai alat penentunya, setiap data dianalisis melalui metode padan dengan teknik fonetik artikulatoris dan referensial karena penelitian gangguan bunyi afasia motorik tidak terpisahkan dari struktur bunyi dalam wujud segmental dan suprasegmental. Setiap data yang dikumpulkan dipilah ke dalam penyimpangan dan penyederhanaan pelafalan bunyi.

\section{Hasil dan Pembahasan}

Berdasarkan arah perubahan bunyi konsonan, diketahui bahwa pergantian bunyi ditemukan mendominasi perubahan bunyi di semua penugasan. Pergantian bunyi dalam afasia Broca tidak bersifat acak, tetapi berdasarkan kondisi lingkungan bunyi. Berdasarkan jenis alterasi fonologis tuturan afasia Broca yang ditemukan, fitur-fitur yang paling berpengaruh dalam bunyi ujaran penutur afasia Broca adalah [+tinggi, +anterior, +koronal, +bersuara, dan +lateral]. Penelitian ini berbeda dengan hasil penelitian yang dilakukan oleh Alqahtani (2019: 462) yang meneliti produksi konsonan oleh tiga pasien afasia dan apraksi melaporkan bahwa fonem dengan tingkat kompleksi- tas rendah (markedness) lebih cenderung diganti oleh fonem dengan tingkat kompleksitas tinggi (marked). Namun, hasil penelitian ini berbeda dengan penelitian yang dilaksanakan oleh Cera \& Ortiz (2010: 61) yang menemukan hasil berlawanan pada produksi konsonan pada pasien afasia dan apraksia, yaitu pergantian ciri bermarkah dan kebermakahan secara statistik lebih tinggi dari kebermarkahan pada ciri bermarkah. Ketimpangan ini bisa dijelaskan oleh perbedaan dalam bahasa pasien yang diujarkan dan sampel yang sedikit. Aspek ini tidak dianalisis dalam penelitian sebelumnya.

\subsection{Hasil}

Diantara 12 fitur yang ditetapkan, fitur paling banyak frekuensinya dalam pergantian fonem adalah fitur [+tinggi]. Terdapat kecenderungan fitur [+tinggi] diganti oleh fitur [+rendah], misalnya bunyi /i/ diganti oleh bunyi /a/ atau konsonan / k/ diganti oleh /h/. Fenomena ini secara akustik disebabkan pelemahan pada pemrosesan artikulatoris (Boyce, 2015: 261). Terkait penyuaraan, bunyi bersuara lebih banyak dipengaruhi oleh bunyi 
tak bersuara. Berbeda dengan penelitian Cera \& Ortiz (2010: 61) yaitu fitur yang lebih mendominasi adalah [+bersuara] dan fitur [+tinggi]. Sementara itu, penelitian ini menunjukkan dominansi fitur [+anterior] menggantikan fitur [+koronal] dan [-anterior,-koronal]. Bunyi dengan fitur [hambat] lebih banyak diganti oleh fitur [kontinyuan].

Pergantian fitur satu dengan fitur yang lain pada umumnya sejalan dengan syarat fitur yang ditetapkan dalam hirarki sonoritas yaitu dimulai dari yang paling tidak sonoran menuju paling sonoran kemudian turun lagi (drop) menuju fitur ke suku kata berikutnya. Prinsip rangkaian suku kata bertujuan untuk menjelaskan pengaturan segmen dalam suku kata dengan memposisikan hubungan sintagmatik antara segmen sonoritas berkerabat. Pendekatan ini melihat puncak silabel (biasanya vokal) terangkai oleh naiknya sonoritas dari onset silabel ke puncak dan kemudian penurunan sonoritas dari puncak suku kata ke koda. Eksponen yang ideal dari sebuah prinsip dari obstruent mengambil posisi onset dan koda. Hal itu menghasilkan perbedaan maksimum dalam sonoritas antara posisi tersebut dengan puncak. Dengan demikian onset dan koda mengandung lebih dari satu segmen, prinsip rangkaian suku kata mempre- diksi bahwa hirarki sonoritas mulai memainkan peranannya di semua proses fonologis. Berikut adalah hasil analisis hubungan pergantian fitur dengan hirarki sonoritas dalam suku kata bahasa Bali ujaran pasien afasia Broca.

\subsubsection{Pergantian Fitur}

Pergantian sonoritas (sonority substitution), yaitu pergantian bunyi satu dengan bunyi yang lain hanya setingkat lebih sonoran menuju puncak silabel, yaitu vokal; bunyi yang paling sonoran dalam hirarki skala sonoritas (Bastiaanse dkk., 1994: 252). Dari data di atas, diketahui pergantian bunyi hanya setingkat lebih sonoran disebut dengan substitusi sonoritas. Semakin sonoran bunyi itu semakin mudah untuk dilafalkan. Bunyi target /sumpin/ dilafalkan [numpin] yang mana /s/ menjadi [n] di awal kata. Alterasi obstruen menjadi nasal karena proses penyesuaian fitur bunyi atau asimilasi regresif, yaitu bunyi bilabial nasal /m/. Proses fonologis ini terjadi akibat ketidakmampuan pasien mengucapkan / s/ di awal kata sehingga mengganti bunyi tersebut dengan bunyi yang memiliki fitur lebih sonoran. Pergantian sonoritas dipresentasikan pada Tabel 2.

Tabel 2.

Pergantian Fitur

\begin{tabular}{|c|c|c|c|c|}
\hline Kata yang dituju & & Realisasi & Segmen yang dituju & Realisasi segmen \\
\hline sumpiy/ sumpin/ & 'kue' & [numpin] & /s/ (level 5) & [n] (level 4) \\
\hline lampu /lampu/ & 'lampu' & [lalpu] & /m/ (level 4) & [1] (level 3) \\
\hline warung / waron/ & 'warung' & [luwon] & /r/ (level3) & [w] (level 2) \\
\hline
\end{tabular}

Pergantian bunyi di atas merupakan fenomena artikulasi atau konseptual, artinya pergantian merupakan perubahan konsepkonsep yang melekat pada segmen tersebut terhadap gerak artikulator. Pergantian fitur bunyi satu akan mempengaruhi pergantian fitur yang lain. Jika sebuah fitur berubah maka fitur lain juga berubah (Romani \& Calabrese, 1998: 90). Berikut ialah diagram pergantian fitur berdasarkan skala hirarki suku kata. 
Bagan 1.

Pergantian $/ \mathrm{s} / \rightarrow[\mathrm{n}] / \#-$

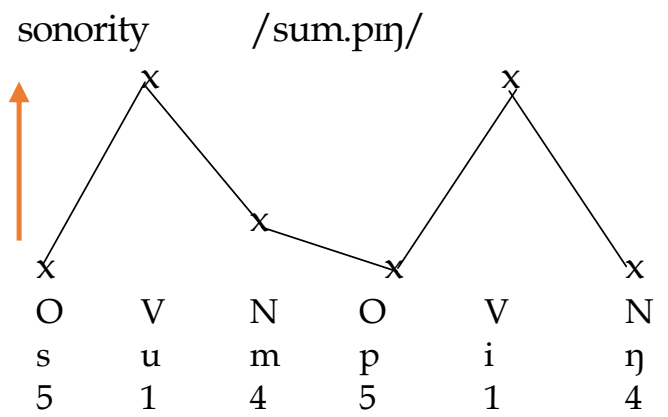

Terdapat pergantian segmen bunyi /s/ di level 5 menjadi [n] di level 4 di awal kata. Pergantian bunyi /s/ menjadi [n] bukanlah pilihan acak, namun berdasarkan hirarki sonoritas yang mana hanya /n/ yang paling layak menggantikan /s/. Bunyi /s/ dan /n/ memiliki beberapa ciri yang sama, yaitu [+anterior, +koronal]. Perbedaannya adalah /s/ memiliki fitur [- nasal, - bersuara] sedangkan /n/ memiliki fitur [+ nasal, + bersuara]. Ini juga diasimilasi oleh lingkungan fitur [nasal] sebelumnya, yaitu bunyi /m/. Dari hirarki sonoritas bunyi [n] setingkat lebih sonoran dari pada [s]. Pergantian sonoritas ke-

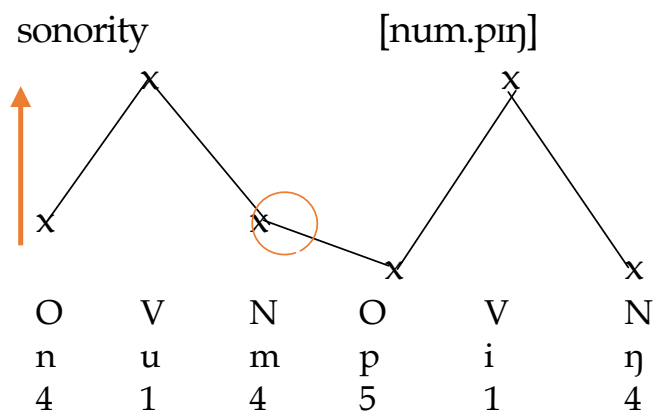

dua adalah bunyi / $\mathrm{m} /$ pada level 4 memi-liki fitur [+anterior, + nasal, -lateral] diganti oleh bunyi yang setingkat lebih sonoran, yaitu /1/ pada level 5, dengan fitur [+posterior, -nasal, +lateral] akibat proses asimilasi bunyi sebelumnya (asimilasi regresif) yaitu /1/. Pelafalan /lampu/ menjadi [lalpu] menggambarkan tingkat kesulitan artikulator dalam mengeksekusi bunyi bilabial nasal. Pasien tidak sempat menutup bibir dan menurunkan velum agar arus udara keluar menuju rongga hidung. Berikut adalah diagram pergantian bunyi /m/ menjadi /1/ berdasarkan skala hirarki suku kata.

Bagan 2.



Pergantian ketiga, yaitu / warung/ dilafalkan [luwuy] yang mana segmen yang dimaksud adalah bunyi /r/ dengan fitur [+anterior, + koronal, -bulat] diganti oleh /w/ dengan fitur [+tinggi, + belakang, +bulat]. Pergantian bunyi dari level 3 direalisasikan

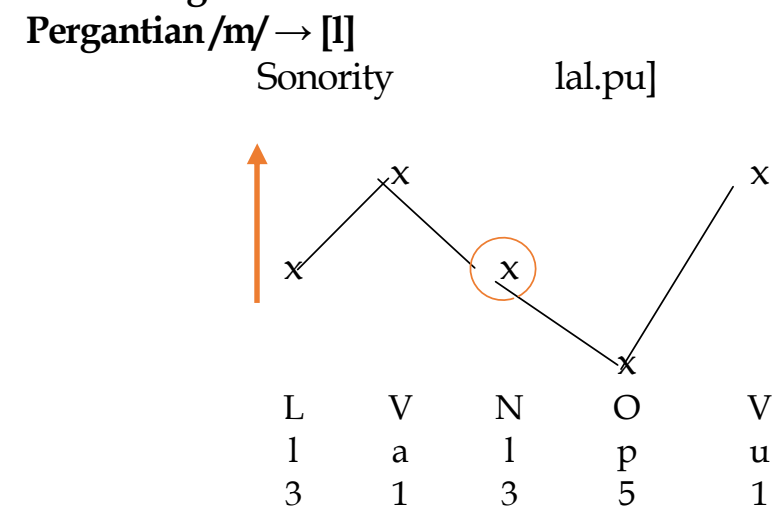

menjadi bunyi di level 2 dalam perangkingan skala sonoritas. Dari pengamatan, pasien tidak bisa melafalkan / $\mathrm{r}$ / di semua posisi sehingga sering diganti dengan bunyi yang paling berkerabat, yaitu /1/. 


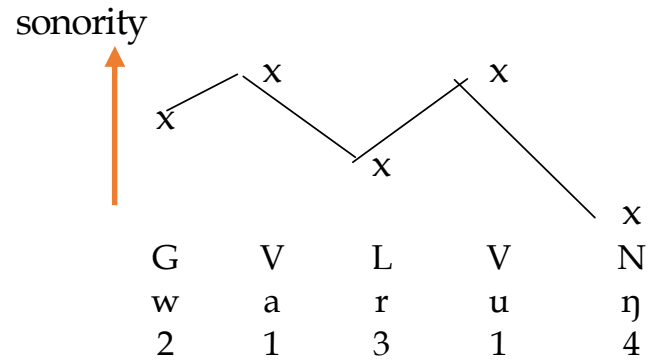

Pergantian bunyi dari satu tingkat ke tingkat lainnya dalam hirarki skala sonoritas merupakan deskripsi alamiah kompleksitas gerakan runut alat ucap. Semakin jauh fitur bunyi pengganti dari puncak silabel, segmen tersebut semakin tidak sonoran dan dikategorikan bermarkah. Romani \& Calabrese (1998: 81) melaporkan adanya pengaruh siste-matis dari sonoritas berdasarkan komplek-sitas artikulasi dalam afasia. Silabel dinyatakan baik apabila garis level sonorannya tajam dari paling tak bersuara dengan fitur [+konsonantal, - malar, -bersuara] di awal silabel. Namun pergantian fitur fonem dalam ujaran afasia motorik tidak dapat mengubah struktur internal suku kata namun dapat menghasilkan kata tanpa makna (Meier et al., 2016 85).

\subsubsection{Penyisipan Fitur}

Selama ini hanya ditemukan pergantian sonoritas, namun ditemukan semua proses fonologis yang dipolakan dalam kaedah prinsip
Bagan 3.

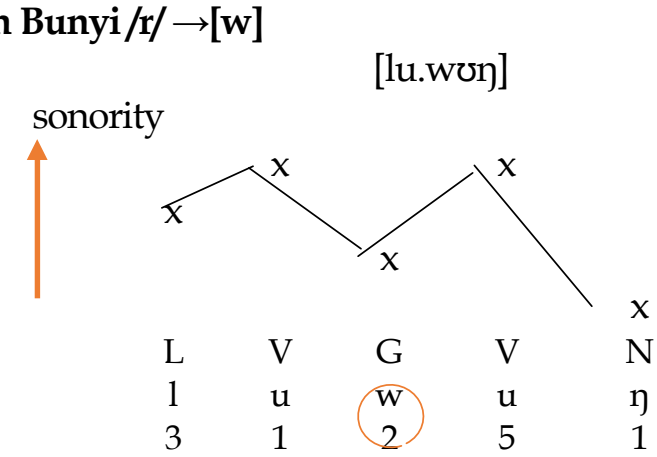

rangkaian sonoritas. Dalam penelitian ini ditemukan penyisipan sonoran (insertion sonority) di antara konsonan dan vokal, yaitu penambahan satu bunyi yang memiliki nilai sonoritas setingkat lebih tinggi dengan bunyi sebelumnya. Jika nilai sonoritas berubah maka struktur internal suku kata juga berubah. Bunyi target /manas/ direalisasikan oleh pasien afasia Broca menjadi [manles]. Proses ini memunculkan struktur suku kata yang baru, yaitu konsonan deret. Penyisipan ini menimbulkan pergantian bunyi rendah belakang /a/ menjadi bunyi sedang depan /e/. Ini membuktikan suatu kaidah baru yaitu perubahan segmen satu akan diikuti oleh perubahan bunyi di lingkungan tersebut. Penyi-sipan terjadi, ketika pasien tidak dapat mela-falkan /a/ sebagai puncak silabel pada suku kata kedua, sehingga diperlukan bunyi yang lebih sonoran dari pada nasal, yaitu likuid. Berikut adalah diagram pergantian fitur dalam hirarki suku kata.

\section{Bagan 4.}

\section{Penyisipan/1/}
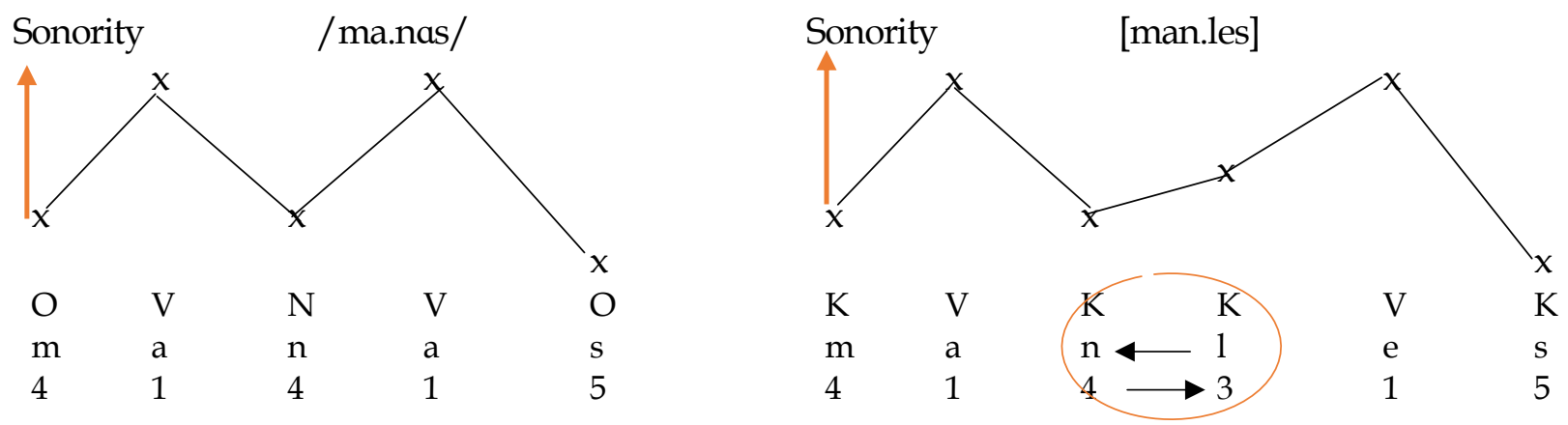
Penyisipan membuat perubahan struktur suku kata semula, yaitu /n/ yang merupakan onset suku kata kedua menjadi koda suku kata pertama setelah penyisipan /1/. Penyisipan ini memunculkan konsonan deret yang mana kedua segmen memiliki beberapa kesamaan fitur, yaitu [+anterior, + koronal, + sonoran]. Fitur pembeda kedua segmen ini adalah fitur [+nasal] dan [-lateral]. Dengan demikian terdapat penyisipan level 3 pada lingkungan level 4 akibat kekerabatan fitur.

\subsubsection{Pelesapan Fitur}

Bunyi selalu berjejer dalam kaidah struktur internal suku kata. Jika bertentangan dengan kaidah ini maka bunyi yang dihasilkan menjadi ambigu dan tidak bermakna (Meier et al.,

\section{Bagan 5.}

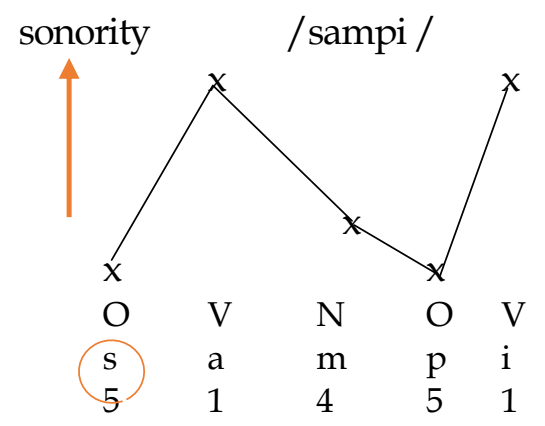

\section{Pelesapan Sonoritas}

Pelesapan fitur dalam rangkaian suku kata dapat mengubah struktur internal dan jumlah suku kata. Pelesapan bunyi dalam ujaran afasia diidentifikasikan sebagai anomia fonologi, yaitu kesulitan mengawali kata. Beberapa bukti menunjukkan bahwa pasien dapat mengucapkan /s/di akhir dengan sem-purna, namun mengalami gangguan di awal kata. Pelesapan fonem di level 5 sering terjadi karena tingkat kompleksitas gerakan artikulasi dan memiliki jarak yang jauh untuk mencapai puncak silabel.

\subsubsection{Metatesis Fitur}

Salah satu proses gangguan fonologis yang ditemukan dalam penelitian ini adalah ada-
2016: 725). Hirarki sonoritas memiliki peranan untuk meyeleksi fitur bunyi apasa saja yang berterima untuk bisa menggantikan, melesapkan atau menyisipkan bunyi target. Namun, pelesapan fonem merujuk pada logika aturan suku kata tersebut. Misalnya kata sampi 'sapi' dilafalkan [ampi]. Pelesapan bu-nyi /s/ pada kata sampi karena kelompok fitur [+obstruen] jaraknya empat tingkat untuk mencapai puncak sonoritas [+silabis] sehingga tidak mungkin mengganti atau menyisipkan fonem baru. Sehingga fonem /s/ dilesapkan dan onset dimulai dari fonem yang paling sonoran, yaitu /a/. Berikut adalah diagram pelesapan fitur dalam hirarki suku kata.



nya mutasi bunyi target ke posisi lain berdasarkan hirarki sonoritas yang ditetapkan sehingga menunjukkan bentuk baru tanpa mengubah struktur internal suku kata. Seperti pada data di atas, pasien afasia kesulitan untuk melafalkan bunyi /s/ di awal namun dapat melafalkannya di akhir suku kata. Seperti kata siap 'ayam' yang dilafalkan [ipas] dengan pola 1-2-3-4 menjadi 2-4-3-1. Pada kata siap, puncak silabel terdapat vokal deret atau diftong namun pasien afasia Broca memutasi bunyi /i/ ke awal sebagai onset suku kata pertama. Berikut adalah diagram metatesis segmen bunyi dalam kata siap melalui hirarki suku kata. 




\subsubsection{Pelanggaran Sonoritas}

Susunan fitur-fitur mengikuti skala sonoritas yang baku dari yang paling tidak sonoran menuju ke yang paling sonoran dan turun lagi. Kompleksitas hirarki berbasis sonoritas memiliki pola yang berterima dalam suatu kaidah, ada juga yang tidak berterima di posisi tertentu karena bahasa itu tidak mengizinkan pola tersebut. Dalam pergantian bunyi, pasien tidak hanya memilih bunyi setingkat atau dua tingkat lebih mudah dilafalkan, tetapi ada kecenderungan melanggar kaidah melalui pergantian fitur dari paling sonoran ke yang paling tidak sonoran atau diantara kelompok fitur yang sama.

\subsubsection{Pergantian fitur dalam satu kelompok} Segmen bunyi dalam satu level fitur hirarki sonoritas digantikan oleh level hirarki seting- kat lebih sonoran atau meloncati dua fitur sekaligus telah ditemukan dalam penelitian ini. Kaidah ini berlaku dari kanan ke kiri dalam satu kelompok fitur sonoritas. Dalam penelitian ini, fitur-fitur obstruen juga dikelompokkan ke dalam perangkingan dari yang paling tidak sonoran ke yang paling sonoran. Fitur obstruen terdiri atas fitur [-malar, bersuara], [-malar, +bersuara], [+anterior, +koronal, + malar] dan [+kasar, +pts]. Namun, pasien menggantikan bunyi tersebut dengan bunyi yang memiliki kedekatan fonologis. Semakin dekat jarak kedekatan sonoritasnya, semakin mudah bunyi itu dilafalkan. Contoh pergantian bunyi dalam kelompok fitur sonoritas disajikan dalam Tabel 3.

Tabel 3

Pelanggaran Pergantian Sonoritas

\begin{tabular}{|c|c|c|c|c|}
\hline Kata yang dituju & & Realisasi & Segmen yang dituju & Realisasi segmen \\
\hline kase / kasə/ & 'kain' & [sasə] & /k/ (level 5.4) & [s] (level 5.2) \\
\hline entip / əntıp/ & 'kerak nasi' & [əmpil] & /n/ (level 4.2) & [m] (level 4.1) \\
\hline rare / rare/ & 'bayi' & [lale] & /r/ (level 3.2) & [1] (level 3.1) \\
\hline uyah / uyah/ & 'garam' & [uwas] & /y/ (level 2) & [w] (level 2) \\
\hline
\end{tabular}

Pergantian bunyi dijelaskan sebagai fenomena artikulasi, artinya penutur memiliki pilihan pelafalan bunyi berdasarkan kemudahan artikulasi. Alterasi bunyi ujaran pasien afasia Broca juga dipengaruhi oleh tingkat kompleksitas artikulasi masing-masing segmen yang dipresentasikan dalam fitur-fitur bunyi. Semakin minim letak perbedaan fitur bunyi satu dengan yang lainnya, maka bunyi itu semakin mendekati normal. Berikut penje- 
lasan pergantian bunyi dalam satu kelompok fitur. Fitur yang terdiri atas [-malar, -bersuara, +tinggi] diganti dengan bunyi yang memiliki fitur setingkat lebih sonoran dalam kelompok obstruen, yaitu [+anterior, +koronal, + malar- bersuara]. Pemilihan ini disebabkan ketidakmampuan pasien melafalkan / k/ di awal kata dilingkungan /s / di suku kata kedua. Berikut adalah diagram pergantian bunyi / $\mathrm{k} /$ menjadi /s/.

\section{Bagan 7}

\section{Pelanggaran Pergantian Satu Kelompok Obstruen}

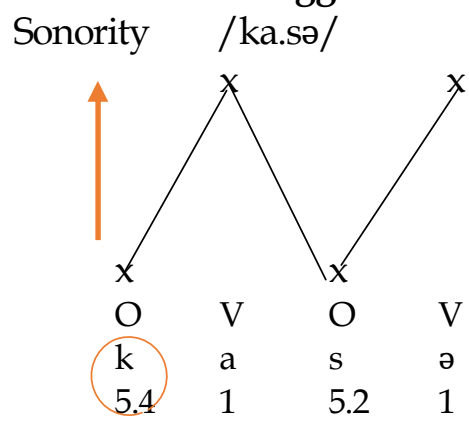

Bunyi dengan fitur [+anterior, +koronal, +nasal, -malar] diganti dengan fitur [+anterior,+nasal, -malar] di lingkungan bunyi [+anterior, -bersuara, -malar]. Artinya bunyi /n/ berpasangan dengan /t/ karena sama-sama alveolar, dan /m/ berpasangan

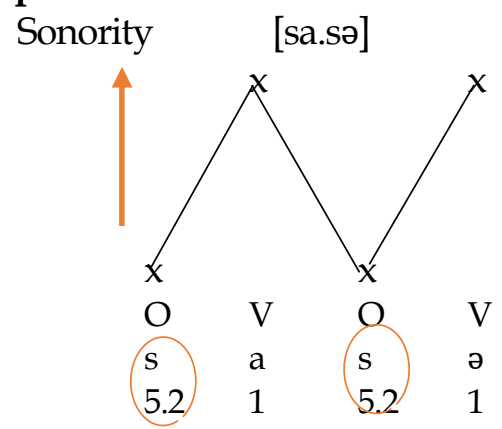

dengan [p] karena keduanya bunyi bilabial. Apabila bunyi /n/ diganti oleh /m/ maka bunyi /t/ diganti dengan bunyi [p]. Berikut adalah diagram pergantian bunyi /n/ menjadi $/ \mathrm{m} /$.

Bagan 8



Penderita afasia dalam penelitian ini tidak bisa melafalkan bunyi getar dengan fitur [+kon, +ant, +kor, +malar dan +son] di semua posisi. Pilihan penggantinya ialah bunyi /1/ karena memiliki banyak ciri pembeda yang relatif sama, yaitu [+kon, +ant, +kor, +malar dan +son]. Ketidakmampuan pasien melafalkan bunyi getar karena faktor kompleksitas artikulasi sehingga saat eksekusi bunyi, pasien melafalkan bunyi /r/ dengan bunyi /1/ karena memiliki kedekatan fitur berkerabat. 


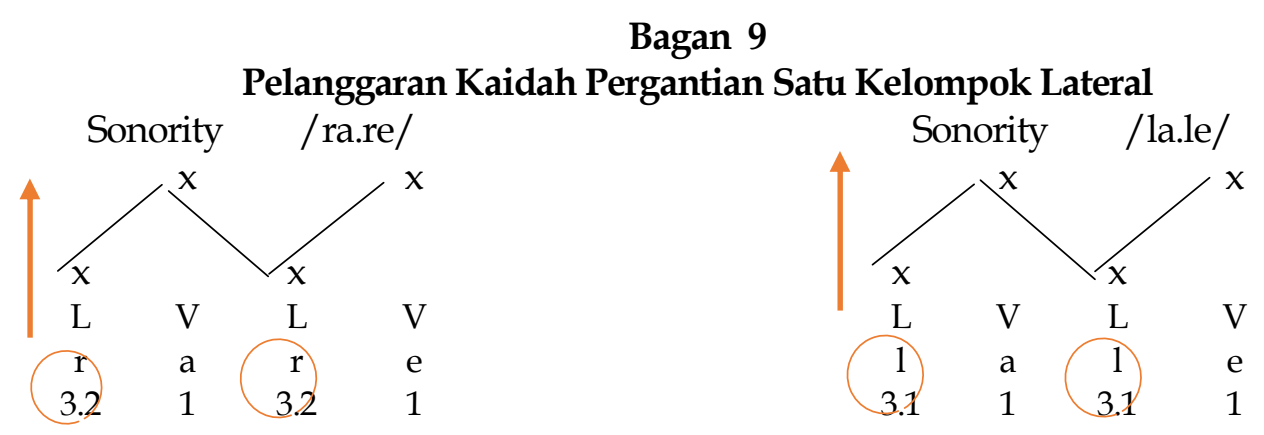

\subsubsection{Pergantian [+sonoran] ke [-sonoran]}

Salah satu gejala baru ujaran pasien Broca berupa pelanggaran hirarki sonoritas dengan mengubah arah pergantian, yaitu dari bunyi sonoran ke arah bunyi yang tidak sonoran. Kaidah baru ini mengacu pada pergantian berdasarkan kedekatan fitur dengan mengabaikan tingkat sonoritas bunyi. Adapun bentuk-bentuk pelanggaran hirarki sonoritas dalam proses asimilasi dapat disajikan pada Tabel 4.

Tabel 4

Pergantian Sonoritas dalam Proses Asimilasi

\begin{tabular}{|c|c|c|c|c|}
\hline Kata yang dituju & & Realisasi & Segmen yang dituju & Realisasi segmen \\
\hline $\begin{array}{l}\text { lindung /lindung/ } \\
\text { tomat / tomat/ }\end{array}$ & $\begin{array}{l}\text { 'belut' } \\
\text { 'tomat }\end{array}$ & $\begin{array}{l}\text { [nindung] } \\
\text { [opat] }\end{array}$ & $\begin{array}{l}\text { /1/ (level 3) } \\
/ \mathrm{m} / \text { (level 4) }\end{array}$ & $\begin{array}{ll}\text { [n] } & \text { (level 4) } \\
\text { [p] } & \text { (level 5) }\end{array}$ \\
\hline
\end{tabular}

Pergantian bunyi dalam arah pergerakan yang melanggar kaidah sonoritas menunjukkan tipe pergantian khas dengan menggunakan fitur-fitur berkerabat. Penjelasan sebuah kaidah hirarki sonoritas merupakan fenomena bunyi pada tataran fonemis dan fonetis. Fitur [+ lat] dalam kata 'lindung' memiliki kekerabatan tempat artikulasi dengan semua bunyi alveolar, yaitu /t/, /d/, /s/, /r/ dan /n/. Bunyi yang setingkat lebih sonoran dari /1/ adalah bunyi semivokal, namun karena fitur-fitur semivokal tidak memiliki kekeraba- tan erat dengan bunyi la-teral maka bunyi /y/ dan / w/ tidak menjadi pilihan pengganti bunyi /1/ ketika tidak da-pat dilafalkan di awal kata tersebut. Pilihan fitur yang dapat diprediksi untuk mengganti bunyi /1/ adalah segmen bunyi yang memiliki fitur [+nasal, +sonoran] karena ada pada lingkungan [+nasal], namun ini tidak sesuai dengan hirarki sonoritas. Berikut dapat disajikan diagram pola pelanggaran pergantian hirarki sonoritas.

Bagan 10

Pelanggaran Kaidah Pergantian Terbalik

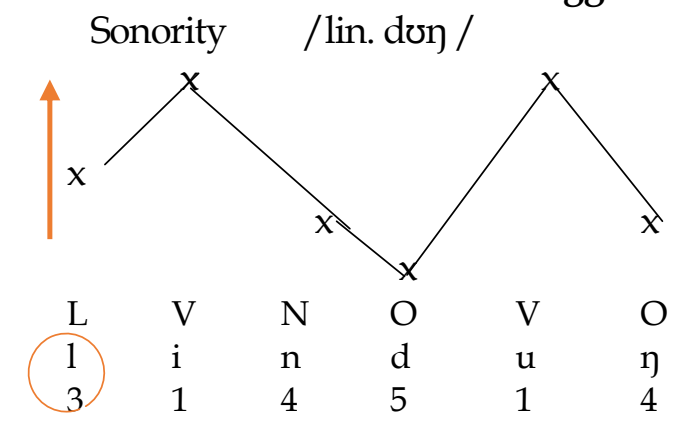

Sonority [lin.don]

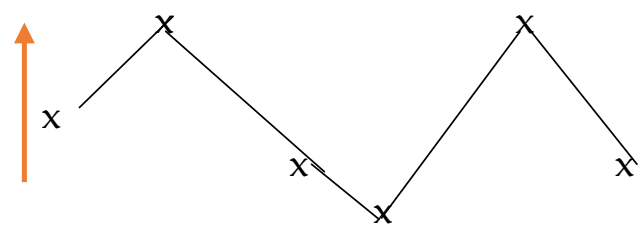

$\begin{array}{llllll}\mathrm{N} & \mathrm{V} & \mathrm{N} & \mathrm{O} & \mathrm{V} & \mathrm{O} \\ \mathrm{n} & \mathrm{i} & \mathrm{n} & \mathrm{d} & \mathrm{u} & \mathrm{n} \\ \mathrm{n} & \mathrm{i} & 4 & 5 & 1 & 4\end{array}$


Bukti pelanggaran lain juga dapat dilihat pada pelemahan bunyi yang memiliki fitur [+anterior, +nasal] semestinya diganti dengan bunyi yang setingkat, seperti [+likuid] atau [semivokal]. Namun, pasien afasia Broca lebih cenderung memilih bunyi yang memiliki fitur yang memiliki kekerabatan yang kuat atau homorgan, yaitu [+anterior, -nasal,]. Pergantian bunyi / $\mathrm{m} /$ dalam penelitian ini tidak ha- nya berdasarkan kedekatan fitur pengganti, yaitu antara /p/ dan /b/, namun ditentukan lingkungan bunyi dalam kata tersebut. Sehingga /m/ diganti dengan /p/ karena berada di lingkungan bunyi tak bersuara di akhir kata /t/. Berikut dapat disajikan diagram pola pelanggaran pergantian hirarki sonoritas.

\section{Bagan 11}

Pelanggaran Pergantian Kelompok lateral

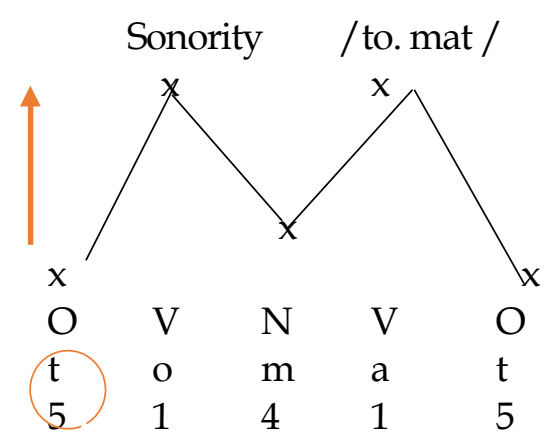

\subsection{Pembahasan}

Berdasarkan analisis data di atas, pada pelemahan bunyi target dapat dikatakan pasien afasia Broca memiliki kecenderungan memilih fonem pengganti, baik dengan mengikuti pola hirarki sonoritas (Bastiaanse et al., 1994: 254) maupun menggunakan fitur-fitur yang memiliki kekerabatan fonologis (Alqahtani, 2019). Konfigurasi bunyi dapat memenuhi kriteria hirarki sonoritas, namun menghasilkan luaran bahasa yang sulit dimengerti. Bastiaanse et al. (1994: 255) menyatakan bahwa semakin tajam peningkatan sonoritas antara awal suku kata dan inti semakin baik suku kata itu. Pergantian, penyimpangan, pelemahan, penambahan dan metatesis bunyi dalam pelemahan bunyi bahasa merupakan penjabaran pelemahan neuronal tataran fonemis dan fonetis (Gandour, 1998: 215). Semakin tinggi kompleksitas artikulasi bunyi target, semakin sering mengalami pelemahan. Fitur bunyi den-



gan kompleksitas yang tinggi [+ hambat] cenderung diganti dengan bunyi dengan fitur kompleksitas yang lebih rendah [+frikatif]. Dengan demikian, hirarki sonoritas memiliki peranan untuk mengarahkan pasien untuk melafalkan bunyi mendekati akurat.

\section{Simpulan}

Penyederhanaan bunyi oleh pasien afasia Broca tidak terlepas dari gangguan proses mental artikulasi bunyi target akibat kerusakan pada fungsi perencanaan arti-kulasi. Dengan demikian, dapat disimpulkan bahwa bunyi ujaran pasien afasia dengan kompleksitas artikulasi yang tinggi diganti dengan bunyi dengan kompleksitas artikulasi yang rendah. Di antara alterasi bunyi berupa pelesapan, penyisipan, penambahan, meta-tesis, voicing dan devoicing, seperti penelitian terkait sebelumnya, alterasi pergantian bunyi meru- 
pakan yang paling dominan. Pergantian terjadi mengikuti pola skala sonoritas dan dipengaruhi oleh lingkungan bunyi yang berkerabat dengan proses asimilasi regresif dan progresif. Proses fonologis ini terjadi akibat ketidakmampuan pasien mengucap-kan bunyi sehingga mengganti fitur bunyi tersebut dengan segmen yang memiliki fitur lebih sonoran. Semakin sonoran suatu bunyi, semakin mudah bunyi itu dilafalkan. Pergantian fitur satu dengan fitur yang lain pada umumnya sejalan dengan syarat fitur yang ditetapkan dalam hirarki sonoritas. Akan tetapi, penelitian ini menemukan pelanggaran sonoritas melalui pergantian fitur dari paling sonoran ke yang paling tidak sonoran dan pergantian fitur dalam satu kelompok fitur sonoritas. Ada kecenderungan pergantian bunyi dengan bunyi yang memiliki kedekatan fonologis atau phonological neighborhood density. Dengan demikian, PND memiliki peranan untuk mengantarkan pasien untuk melafalkan bunyi mendekati akurat. Pene-litian ini membenarkan bahwa kombinasi segmen yang membedakan lebih tajam dalam sonoritas lebih mudah untuk dihasilkan. Untuk penelitian di masa mendatang, peneliti neurolinguistik maupun linguistik klinis disarankan untuk mengkaji gangguan bunyi pada jenis afasia yang berbeda sehingga dapat ditemukan benang merah cakupan pola perbedaan pergeseran bunyi dan gejala baru pada gangguan berbahasa pasien.

\section{Daftar Pustaka}

Adam, H. 2014. "Dysprosody in aphasia: An acoustic analysis evidence from Palestinian Arabic," Journal of Language and Linguistic Studies, 10(1), 153-162.

Alqahtani, M. S. 2019 “Sonority Sequencing Principle in Sabzevari Persian: A Constraint-Based Approach," Open Linguistics, 5, 434-465. https:// doi:10.1017/CBO97805116277 36.017

Bastiaanse, R., Gilbers, D. dan Linde, K. Der 1994. "Sonority substitutions in Broca's and conduction aphasia," Journal of Neurolinguistics, 8(4). 247255.

https:/ / doi.org/10.1016/09116044(94) 90011-6

Boyce, S. E. 2015. "Articulatory Phonetics for Residual Speech Sound Disorders: A Focus on /r/," Semin Speech Lang., 36(4), 257-270.

https:/ / dx.doi.org/10.1055\%2Fs-00351562909

Buckingham, H. W. dan Christman, S. S. 2008 "Disorders of Phonetics and Phonology," in Handbook of Neuroscience of Language. London: Academic Press, 127-135.

Cera, M. L. dan Ortiz, K. Z. 2010. "Phonological analysis of substitution errors of patients with apraxia of speech," Dement Neuropsychol, 4(1), hal. 58-62. https://doi:10.1590/S198057642010DN40100010

Galluzzi, C. Bureca, I, Guariglia, C, Romani, C. 2015. "Phonological Simplifications, Apraxia of Speech and the Interaction between Phonological and Phonetic Processing," Neuropsychologia, 71, 6483.

https://doi:dx.doi.org/10.1016/j.neur opsychologia.2015.03.007

Gandour, J. 1998. "Phonetics and Phonology," in Whitaker, H. dan Stemmer, B. (ed.) Handbook of Neurolinguistics. Academic Press, 207218. 
Herbert, R. E. 2004. Therapy for word finding in aphasia: Effects on picture naming and conversation. University College London. Tersedia pada:

https:/ / discovery.ucl.ac.uk/id/eprint $/ 1446711$

Ingram, J. C. L. 2007. Neurolinguistics An Introduction to Spoken Language Processing and its Disorder. Cambrdge: Cambridge University Press.

Madden, E. B., Robinson, R. M. dan Kendall, D. L. 2017. "Phonological Treatment Approaches forSpoken Word Production in Aphasia," Seminnars in Speech and Language, 38(1), 62-73. https://doi: 10.1055/s0036-1597258

Meier, E. L., Lo, M. dan Kiran, S. 2016. "Understanding semantic and phonological processing deficits in adults with aphasia: Effects of category and typicality," Aphasiology, 30(6),719-749.

https:// doi:I10.1080/02687038.2015.10 81137

Novick, J., Trueswell, J. C. dan ThompsonSchill, S. L. 2010. "Broca's Area and Language Processing: Evidence for the Cognitive Control Connectione," Language and Linguistics Compass, 4(10), 906-924. doi: 10.1111/j.1749818X.2010.00244.x

Odden, D. 2005. Introducing Phonology. Cambridge: Cambridge University Press.
Romani, C dan Calabrese, A. 1998. "Syllabic Constraints in the Phonological Errors of an Aphasic Patient," Brain Lang, 64(1), 83-121.

https:/ / doi: 10.1006/brln.1998.1958

Sastra, G. 2011 Neurolinguistik suatu Pengantar. Bandung: Alfabeta.

Schane, S. A. 1973. Generative Phonology. San Diego: Prentice-Hal, Inc.

Solomon, N. dan Munson, B. 2004. “The Effect of Jaw Position on Measures of Tongue Strength and Endurance," Journal of Speech Language and Hearing Research, 47(3), 584-94. https:/ / doi:10.1044/10924388(2004/0 45

Wardana, I. K., Suparwa, I. N. dan Budiarsa, M. 2018. "Phonological Errors on Impaired Language Modality Produced by Individuals with Broca's Aphasia," International Journal of Linguistics, 10(6), 227-244. doi:10.5296/ijl.v10i6.13893

Wardana, I. K., Suparwa, I. N, Budiarsa, M. Putra, P. A. A 2019. "Phonological Errors of Broca's Aphasia: A Single Case Study of Neurolingusitics," $e$ Journal of Linguistics, 13(1), 142-157. https:// doi:10.24843/eJL.2019.v.13 i01.p.13. 